AUTHORS AND AUTHORITY 
By the same author

H. G. Wells

Science Fiction: Its Criticism and Teaching

James Joyce

The Failure of Theory: Essays on Criticism and Contemporary

Fiction

(as editor)

H. G. Wells: The Critical Heritage

Science Fiction: A Critical Guide

H. G. Wells' Literary Criticism (with Robert M. Philmus)

H. G. Wells Under Revision (with Christopher Rolfe) 


\section{AUTHORS AND AUTHORITY}

English and American Criticism 1750-1990

Patrick Parrinder

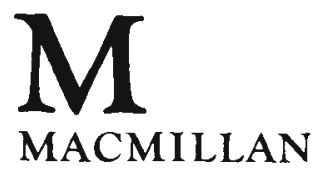


(C) Chapters 1-4 Patrick Parrinder 1977, 1991

(C) Chapters 5-7 Patrick Parrinder 1991

Chapters 1-4 of this book were first published in a slightly different form as Authors and Authority: A Study of English Literary Criticism and its Relation to Culture 1750-1900 by Routledge and Kegan Paul 1977

All rights reserved. No reproduction, copy or transmission of this publication may be made without written permission.

No paragraph of this publication may be reproduced, copied or transmitted save with written permission or in accordance with the provisions of the Copyright Act 1956 (as amended), or under the terms of any licence permitting limited copying issued by the Copyright Licensing Agency, 33-4 Alfred Place, London WC1E 7DP.

Any person who does any unauthorised act in relation to this publication may be liable to criminal prosecution and civil claims for damages.

First published 1991

Published by

MACMILLAN EDUCATION LTD

Houndmills, Basingstoke, Hampshire RG21 2XS

and London

Companies and representatives

throughout the world

British Library Cataloguing in Publication Data

Parrinder, Patrick 1944

Authors and authority: English and American criticism 1750-1990.

1. English literature. Criticism, history 2. American

literature. Criticism, history

I. Title

801.950942

ISBN 978-0-333-43295-2

ISBN 978-1-349-21479-2 (eBook)

DOI 10.1007/978-1-349-21479-2 


\section{Contents}

Preface

Introduction

vii

1

1 Samuel Johnson: The Academy and the Market-Place 6

Neoclassicism: Dryden and Pope 6

Minim, the Dictionary and the Life of Savage 18

Milton, Shakespeare and the Lives of the Poets 29

2 William Wordsworth: The Poet as Prophet 38

Sublimity and transcendence: the later Eighteenth Century 38

The Preface to Lyrical Ballads 44

Poetic power: Wordsworth and de Quincey 56

3 The Romantic Critics 64

Reviewers and Bookmen: from Jeffrey to Lamb 64

Samuel Taylor Coleridge $\quad 74$

Biographia Literaria $\quad 74$

Coleridge on Wordsworth $\quad 87$

Shakespearean Criticism 95

Shelley, Hazlitt and Keats 99

Shelley's 'Defence of Poetry' 102

Hazlitt and Keats $\quad 105$

$\begin{array}{ll}\text { Hazlitt and de Quincey } & 112\end{array}$

4 Victorian Criticism: The Republic of Letters 117

The Definition of Literary Culture 117

Thomas Carlyle $\quad 125$

Tennyson and Mill 129

The Birth of American Criticism: Emerson, Whitman and Poe 134

Ruskin and Morris 139

Matthew Arnold 143

Homer and the Grand Style 146

Essays in Criticism and Culture and Anarchy 155

Essays in Criticism: Second Series and other later

The later Nineteenth Century 177

$\begin{array}{ll}\text { Walter Pater } & 178\end{array}$

Swinburne's Criticism $\quad 185$ 
Harrison and Saintsbury $\quad 189$

The Genteel Tradition and Henry James 190

Leslie Stephen and A. C. Bradley 196

W. B. Yeats 201

5 Modernists and New Critics 207

The Children of the New Epoch: Lewis, Pound and Hulme 207

T. S. Eliot 214

Eliot as modernist 216

The Sacred Wood and the dissociation of sensibility 221

The later Eliot $\quad 226$

Poetry and the Age (1920-60) 233

I. A. Richards 234

Leavis and the Southern Agrarians 243

Leavis on poetry 246

Leavis and Lawrence $\quad 252$

Williams, Caudwell and Orwell 255

The New Critics: Ransom, Burke, Blackmur and Winters 259

6 The Age of Interpretation 270

The Scientific Schoolmen $\quad 270$

William Empson $\quad 274$

Northrop Frye $\quad 281$

Roman Jakobson $\quad 287$

Theory and Interpretation: the Text and the Dream 293

Freud and deconstruction $\quad 295$

Harold Bloom $\quad 300$

$\begin{array}{ll}\text { Paul de Man } & 306\end{array}$

7 The Challenges to Interpretation $\quad 314$

The Men of Letters: Wilson, Trilling and Steiner $\quad 314$

Edmund Wilson $\quad 315$

Lionel Trilling $\quad 320$

George Steiner 324

Virginia Woolf and Feminist Criticism 326

Literary Criticism and Cultural Theory 337

Notes $\quad 350$

Guide to Further Reading $\quad 374$

Index $\quad 384$ 


\section{Preface}

The first four chapters of Authors and Authority, with the subtitle 'A Study of English Literary Criticism and its Relation to Culture 1750-1900', were published by Routledge and Kegan Paul in 1977. The book was not originally meant to stop at 1900 , so that the present, greatly enlarged edition represents the fulfilment of my original plan. At the same time, Chapters 5,6 and 7 have been written in the very different intellectual climate of the late 1980s. One of the changes to be recorded is that nobody today discusses the 'decline of English' in the resigned, elegiac tone that was common fifteen years ago. Criticism and English studies have not only revealed great reserves of vitality. but there is a renewed sense of their cultural and educational importance. The relationship of literature to literacy, and the place of English in the national education systems of the English-speaking countries, have continued to be hotly contested.

Another major change is in the currency of the word 'authority'. which in 1977 had scarcely risen to the surface of literary discussion. In the year that the earlier part of Authors and Authority appeared the journal Daedalus published a translation of Jean Starobinski's essay "Criticism and Authority", a brief history of the concept of criticism in France. E. D. Hirsch, Jr's Validity in Interpretation, published ten years earlier, had been one of the first books to bring the terms 'author' and 'authority' together for rhetorical purposes, and by the early $1980 \mathrm{~s}$, in the aftermath of the post-structuralist inquisitions into the Death of the Author and the Myth of the Author, this coupling had become a commonplace. Where Hirsch's theory of reading seeks to reinstate the authority of the author's intention, many of the more recent discussions of literary authority either register its loss or, where it is judged to have survived, they seek to undermine it. The ironies involved were neatly illustrated by a conference of the 'Literature Teaching Politics' group, held in England in 1984: the conference took 'Authority' as its main theme and one of the topics offered was 'The absence of authority as itself authoritative'.

Chapters 1 to 4 have been considerably revised for the present edition. The new Chapters 5,6 and 7 discuss twentieth-century literary criticism written in English, so I have been forced to omit, or to cite in very summary fashion, a good deal of the criticism 
and theory that is currently discussed in university English departments; in some cases this is because I judge it to be ephemeral, but much of the material concerned is either not primarily literary, or is read in translation. Readers chiefly interested in multinational literary theory will find structuralism and deconstruction discussed in Chapter 6, and feminism and cultural theory in Chapter 7, with emphasis on the major English-language critics in each field. The future of a strictly literary criticism is also questioned - and reaffirmed - in these chapters.

For Chapters 5,6 and $7 \mathrm{I}$ am grateful for the encouragement provided by Beverley Tarquini and Caroline Egar at Macmillan, and the resources of the universities of Reading and California (Santa Barbara), where they were written. Coral Howells and Jenny Taylor gave generous encouragement and support, as well as stern criticism of my attempts to deal with feminist theory. Above all, I must thank Lilian Argrave for her patience and expertise during many hours of word-processing, and Jenny Bevan for her assistance. My debts to family, friends, colleagues and students, in a book first conceived at the University of Cambridge nearly two decades ago, are quite simply too numerous to mention. I would like, however, to dedicate this edition of Authors and Authority to the memory of three former colleagues and mentors, lan Fletcher, Graham Hough and Raymond Williams. Each of them is present at particular moments in this book but, at a deeper level, their very different lives and outlook embodied the critical vocation as I understand it.

Patrick Parrinder Reading, October 1990 